B I O S C I E N C E

J O U R N A L

\title{
COMPARISONS BETWEEN INTAKE VALUES OBSERVED AND \\ PREDICTED BY NUTRITIONAL SYSTEMS FOR CONFINED NELLORE CATTLE
}

\author{
Aline Maria Soares FERREIRA ${ }^{1}$ (D) Simone Pedro da SILVA $^{2}$ iD, Carina Carina Ubirajara de FARIA ${ }^{2}$ iD, \\ Egleu Diomedes Marinho MENDES ${ }^{3}$ (D), Ester Ferreira FELIPE ${ }^{4}$ iD

\footnotetext{
${ }^{1}$ Post-Graduate Program in Veterinary Science, Federal University of Uberlândia, Uberlândia, Minas Gerais, Brazil.

2 School of Veterinary Medicine, Uberlândia, Minas Gerais, Brazil.

${ }^{3}$ Texas A\&M University, Department of Animal Science, College Station, TX, 77843, United States of America.

${ }^{4}$ Post-Graduate Program in Animal Genetic Improvement, São Paulo State University “Júlio de Mesquita Filho”, Jaboticabal, Minas Gerais, Brazil.
}

Corresponding author:

Simone Pedro da Silva

Email: simone.psilva@hotmail.com

How to cite: FERREIRA, A.M.S., et al. Comparisons between intake values observed and predicted by nutritional systems for confined Nellore cattle. Bioscience Journal. 2021, 37, e37093. https://doi.org/10.14393/BJ-v37n0a2021-54149

\begin{abstract}
This study compared the dry matter intake (DMI) of Nellore heifers and bulls in the feedlot, predicted by the BR-Corte (2010 and 2016) and NRC (2000) nutritional systems. Hence, two experiments were conducted in a completely randomized design. The first one used 47 Nellore bulls, not castrated, with an average initial weight of $413 \mathrm{~kg}$, and 19 months of age. The second experiment used 24 Nellore heifers with an average initial weight of $300 \mathrm{~kg}$ and 23 months of age. The accuracy and approximation of the DMl estimates by the nutritional systems were adjusted with the simple linear regression model and the root mean square error of prediction (RMSEP). The DMI was $8.06 \mathrm{~kg} \mathrm{day}^{-1}$ for Nellore heifers and $11.54 \mathrm{~kg} \mathrm{day}^{-1}$ for bulls, which are higher than the values predicted by the nutritional systems. The NRC (2000) and BR-Corte (2010 and 2016) underestimated DMI in 20.84, 20.09, and $19.35 \%$ for heifers and $28.07,16.20$, and $11.78 \%$ for bulls, respectively. It was concluded that the BR-Corte 2010 and 2016 were the most suitable models to estimate the DMI of Nellore heifers and bulls for higher precision and accuracy.
\end{abstract}

Keywords: Electronic Feeding Systems. Equations. Measurement. Nutrition.

\section{Introduction}

Dry matter intake (DMI) is the most important variable that affects animal performance. According to Mertens (1994), 60 to $90 \%$ of variations in animal performance are explained by consumption and only 10 to $40 \%$ by the effects attributed to the nutritional value characteristics of feed, such as digestibility. This means that maximizing animal performance requires understanding the feed intake of animals, which is an extremely difficult variable to obtain using mathematical models because it is affected by numerous factors related to animal diet, environment, and management, among others.

Nutritional systems such as the National Research Council (NRC), Agricultural and Food Research Council (AFRC), Cornell Net Carbohydrate and Protein System (CNCPS), and BR-Corte have produced empirical models to estimate intake. It is worth noting that the American and British systems developed equations to predict consumption using animals as a database, predominantly Bos taurus. The predominant genetic group in Brazil is Zebu, with a high number of Nellore animals, and the BR-Corte system developed models to estimate consumption in Zebu and crossbred animals. 
This study aimed to compare the observed DMI with the ones predicted by the BR-Corte (2010 and 2016) and NRC (2000) nutritional systems for Nellore heifers and bulls in the feedlot. It also aimed to find the model that makes the best predictions for these categories of cattle.

\section{Material and Methods}

Two experiments were conducted from May to December 2017 at the Capim Branco Farm of the Federal University of Uberlândia (UFU), in Uberlândia, MG, Brazil. The first one used 47 Nellore bulls, not castrated, with an average initial body weight of $413 \mathrm{~kg}$, and 19 months of age, and the second experiment used 24 Nellore heifers with an average initial body weight of $300 \mathrm{~kg}$, and 23 months of age.

In each experiment, the animals were identified with earrings and housed in two partially covered bays equipped with the GrowSafe ${ }^{\mathrm{TM}}$ electronic feeding system to measure the individual intake of the animals (observed DMI). They remained housed for 21 days for adapting to the diet and facilities. The requirements established for formulating the diets were a gain of $700 \mathrm{~g} /$ day for heifers and $1 \mathrm{~kg}$ for bulls using information from the NRC (2000).

The diet provided to the group of heifers contained corn silage as forage (80\%) and a concentrate based on corn meal (12.65\%), soybean meal (4\%), urea (0.35\%), and mineral mixture (3\%). The diet of Nellore bulls contained $60 \%$ of corn silage, $28 \%$ of corn meal, $8 \%$ of soybean meal, $1 \%$ of urea, and $3 \%$ of mineral mixture.

For the chemical composition of the diets, feed samples were taken every 14 days. Chemical analyses were conducted according to Detmann et al. (2012), and the total digestible nutrient (TDN) content was obtained with the NRC (2001) and BR-Corte (2016) equations (Table 1).

Table 1. Chemical composition of the diets of Nellore heifers and bulls.

\begin{tabular}{ccc}
\hline Composition (\%) & Heifers' diet 80:20 & Bulls' diet 60:40 \\
Dry matter & 40.47 & 52.66 \\
Mineral matter & 3.77 & 3.41 \\
Neutral detergent fiber & 41.24 & 33.73 \\
Acid detergent fiber & 23.77 & 18.94 \\
Lignin & 1.87 & 1.85 \\
Crude protein & 9.24 & 11.20 \\
Ethereal extract & 2.28 & 2.52 \\
Neutral detergent insoluble crude protein & 1.18 & 1.32 \\
Acid detergent insoluble protein & 0.89 & 0.91 \\
Non-fibrous carbohydrates & 40.11 & 45.14 \\
Total Digestible Nutrients (NRC, 2000) & 68.10 & 71.36 \\
Total Digestible Nutrients (BR-Corte, 2016) & 69.70 & 74.20 \\
\hline
\end{tabular}

Temperature, relative humidity, and rainy events were monitored with a digital thermometer installed near the confinement. In the experiment with bulls, the average temperature was $21.08{ }^{\circ} \mathrm{C}$ and relative humidity was $54.82 \%$, while in the experiment with heifers, these values were $26.32 \circ \mathrm{C}$ and $54.92 \%$, respectively. Temperature and humidity data were used to calculate the adjustment factors for dry matter intake according to the NRC (2000) equations.

Table 2. Days of intake measurement, body weight measured at the beginning and end of the experiment, and average daily gain of confined cattle.

\begin{tabular}{cccccc}
\hline Category & Diet & Measurement days & BWI & BWF & ADG \\
\hline Nellore heifers & $80: 20$ & 66 & 305 & 347 & 0.634 \\
Nellore bulls & $60: 40$ & 74 & 403 & 528 & 1.68 \\
\hline
\end{tabular}

*BWI: Average initial body weight with 16 hours of solid fasting; BWF: Average final body weight with 16 hours of solid fasting; ADG: Average daily gain. 
The equations used for predicting DMI were from the NRC (2000), NRC (2016)/DMIR approach, BRCorte (2010) for pure Zebu, and BR-Corte (2016) for Zebu, using the level of concentrate in the diet. The variables measured in the experiment were individual dry matter intake and the average daily gain, in which the animals were weighed with 16 hours of feed fasting at the beginning and end of the experiment.

BR-Corte (2010):

DMI $\left(k_{\text { day }}{ }^{-1}\right)=-2.7878+0.08789 \mathrm{BW}^{0.75}+5.0487 \mathrm{ADG}-1.6835 \mathrm{ADG}^{2}$

BW: body weight; ADG: average daily gain.

BR-Corte (2016):

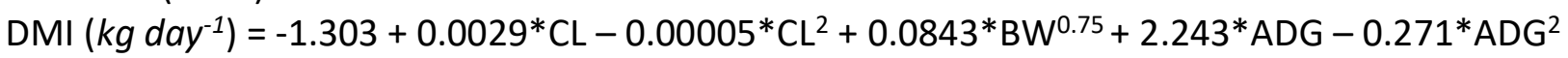

$B W$ : body weight; $C L$ : concentrate level; $A D G$ : average daily gain.

NRC (2000):

DMI $\left(k_{\text { day }}{ }^{-1}\right)=$ BW0.75 * $\left.\left(0.2435 \mathrm{NEm}-0.0466 \mathrm{NEm}^{2}-0.1128\right)\right) / \mathrm{NEm}^{2}$

$B W$ : body weight; NEm: dietary NEm concentration in Mcal $\mathrm{kg}^{-1}$ of DM.

NRC (2016)/ DMIR approach:

DMIR $\left(k_{\text {d day }}{ }^{-1}\right)=[($ NEm required/NEm dietary DM $)+($ NEg required/NEg dietary DM $)]$

NEm required: Mcal per day; NEg required: Mcal per day; NEm: dietary NEm concentration in Mcal $\mathrm{kg}^{-1}$ of DM; NEg: dietary NEg concentration in Mcal $\mathrm{kg}^{-1}$ of DM.

The accuracy appraisal of DMI estimates by the nutritional systems was adjusted with the simple linear regression model of observed values (dependent variable) on predicted values (independent variable), and the statistical tests were performed according to the following hypotheses: $H_{0}: \beta_{0}=0$ and $\beta_{1}=1$ vs. $H_{1}$ : not $\mathrm{H}_{0}$. The probability of type I error used was 0.01 . When rejecting the null hypothesis, the predicted and observed values were similar. Predicted values were plotted on the $X$-axis, while observed values were on the Y-axis, according to Tedeschi (2006).

To assess the prediction efficiency of the models, the decomposition of mean square error of prediction (MSEP) was performed (Kobayashi and Salam 2000). The Model Evaluation System (MES) software was used for analyzing the data and generating plots (Tedeschi 2017).

\section{Results and Discussion}

The mean DMI observed in Nellore heifers was $8.06 \mathrm{~kg}$ day ${ }^{-1}$, which is higher than the predictions of the nutritional systems. The NRC 2000 and 2016 and BR-Corte 2010 and 2016 underestimated the DMI for heifers by $20.84,4.71,20.09$, and $19.35 \%$, respectively (Table 3 ).

Table 3. Descriptive analysis of dry matter intake $\left(\mathrm{kg} \mathrm{day}^{-1}\right)$ values observed and predicted by the nutritional systems for each animal category.

\begin{tabular}{|c|c|c|c|c|c|c|}
\hline \multicolumn{7}{|c|}{ Nellore heifers } \\
\hline \multicolumn{7}{|c|}{ Predicted } \\
\hline & Observed & $\begin{array}{c}\text { Number of } \\
\text { animals }\end{array}$ & $\begin{array}{l}\text { NRC } \\
2000\end{array}$ & NRC 2016 & BR-Corte 2010 & BR-Corte 2016 \\
\hline Minimum & 5.32 & 24 & 5.39 & 5.44 & 4.68 & 5.05 \\
\hline Maximum & 9.42 & 24 & 7.27 & 9.61 & 7.74 & 7.63 \\
\hline Mean & 8.06 & 24 & 6.38 & 7.68 & 6.44 & 6.50 \\
\hline \multicolumn{7}{|c|}{ Nellore bulls } \\
\hline \multicolumn{7}{|c|}{ Predicted } \\
\hline & Observed & $\begin{array}{l}\text { Number } \\
\text { of } \\
\text { animals }\end{array}$ & $\begin{array}{l}\text { NRC } \\
2000\end{array}$ & NRC 2016 & BR-Corte 2010 & BR-Corte 2016 \\
\hline Minimum & 8.80 & 47 & 7.22 & 10.03 & 8.64 & 8.77 \\
\hline Maximum & 15.54 & 47 & 9.50 & 18.20 & 10.84 & 11.63 \\
\hline Mean & 11.54 & 47 & 8.30 & 14.19 & 9.67 & 10.18 \\
\hline
\end{tabular}


Marcondes et al. (2008) verified a mean DMI of $7.61 \mathrm{~kg}$ day $^{-1}$ for Zebu heifers in confinement, with an average initial body weight of $258 \mathrm{~kg}$, and diet with $75 \%$ of forage (corn silage). Valadares Filho et al. (2016) also identified a lower DMI than the present study, with an average DMI of $6.56 \mathrm{~kg} \mathrm{day}^{-1}$ and maximum DMI of $7.22 \mathrm{~kg} \mathrm{day}^{-1}$ for Zebu heifers in confinement, with an average initial body weight of 305 $\mathrm{kg}$, and an average gain of $0.7 \mathrm{~kg} \mathrm{day}^{-1}$.

Nellore bulls presented a mean observed DMI of $11.54 \mathrm{~kg}^{\text {day }}{ }^{-1}$. The values predicted by the NRC 2000 and BR-Corte 2010 and 2016 underestimated DMI values in $28.07 \%, 16.20 \%$, and $11.78 \%$, respectively, and the NRC 2016 overestimated DMI values in 22.96\% (Table 2). Marcondes et al. (2008) and Rubiano et al. (2009) found an intake of $8.41 \mathrm{~kg} \mathrm{MS} \mathrm{day}^{-1}$ for non-castrated Nellore bulls.

In both experiments with Nellore heifers and bulls, the DMI was higher than the values observed in the literature. This may have occurred because the heifers presented a compensatory gain, considering that, before starting the experiment, they were being fed with Brachiaria brizantha cv. Marandu in the dry season and protein supplementation of $0.1 \%$ of BW. This may have caused quantitative and qualitative feed restrictions, thus increasing the consumption of dry matter in the feedlot. Studies conducted by Aferri (2007), and Barbosa et al. (2016) also identified a higher consumption in animals presenting compensatory gain. Moreover, the animals in the present study are from a genetic selection, which can lead to an increased consumption to meet higher nutritional requirements. Such information leads to the need for adjustments in consumption prediction models, considering the genetic potential of the animals and their previous feeding period.

Regarding the average daily gain (ADG), the bulls presented superior performance $\left(1.68 \mathrm{~kg}\right.$ day $\left.^{-1}\right)$ to heifers ( $0.634 \mathrm{~kg} \mathrm{day}^{-1}$ ) (Table 2). Furthermore, Nellore animals gained $0.680 \mathrm{~kg}$ over the estimated value (1 $\mathrm{kg}$ day $^{-1}$ ), which can be explained by the genetic potential of these animals that also participate in performance and feed efficiency tests. Other studies (Fernandes et al. 2004; Paulino et al. 2008) that measured ADG in Nellore beef cattle have identified lower performances than those of the present study. However, the heifers performed slightly below expectations, with $0.634 \mathrm{~kg}^{\text {day }}{ }^{-1}$ instead of $0.700 \mathrm{~kg} \mathrm{day}^{-1}$. This may have been caused by the appearance of estrus in these animals during the trial, considering that nutritional models do not display reduction adjustments for intake and performance due to the reproductive physiology of animals.

Paulino et al. (2008) worked with Nellore males and females on a diet composed of corn silage, fine ground corn, $42 \%$ of cottonseed corn, urea:ammonium sulfate (9:1), limestone, sodium chloride, and mineral mixture at increasing levels of concentrate so that $1.2 \%$ of body weight was offered at the end of the test. Whole males had weight gains of $0.83 \mathrm{~kg} \mathrm{day}^{-1}$, castrated males had $0.69 \mathrm{~kg} \mathrm{day}^{-1}$, and females had $0.66 \mathrm{~kg} \mathrm{day}^{-1}$.

Valadares Filho et al. (2016) stated that the selection of genetically superior qualities for efficiency becomes an urgent need to be implemented in intake prediction models. According to Berchielli et al. (2011), the higher the animal production, the higher the demand for nutrients, consequently increasing dry matter intake. Thus, with the advance of technologies and genetic selection of animals, the influence of the genetic potential on dry matter intake stands out. Such information may justify the higher values of observed intake for Nellore heifers and bulls than those predicted by the nutritional systems (Table 3), which contributes to discussions about the lack of adjustments in the models for the genetic potential of the animals evaluated. Hence, animals present an increase in DMI to gain more weight due to their genetic expression. Therefore, further studies should be performed in this direction so that new adjustments are incorporated into the models.

When comparing the observed DMI with the one predicted by the BR-Corte and NRC nutritional systems (Table 4 ), the simultaneous test for intercept $=0$ and slope $=1$ failed to reject the null hypothesis ( $P$ $<0.001)$ for the different animal categories. This indicates that the models tended to be parallel to lines $Y=$ $X$, concluding that there was a similarity between predicted and observed values. The values of $R^{2}$ (Table 4) explained 7 to $35 \%$ of the variations between observed and predicted values. However, it is inaccurate to say that an $\mathrm{R}^{2}$ close to zero does not indicate a correlation between observed and predicted values, considering that this relationship might be curvilinear (Tedeschi 2006). It is ideal, in these cases, to submit the data to the decomposition of mean square error of prediction (MSEP), according to protocols described by Kobayashi and Salam (2000). 
Table 4. Components of the regression analysis of the observed dry matter intake and the one predicted by the nutritional systems.

\begin{tabular}{cccccccc}
\hline \multicolumn{7}{c}{ Nellore heifers } \\
\hline Models & $\mathrm{R}^{2} \mathrm{a}$ & $\beta_{0}$ & $\beta_{1}$ & SEM & $\begin{array}{c}\mathrm{P}^{1} \\
(\mathrm{H} 0: \beta 0=0)\end{array}$ & $\begin{array}{c}\mathrm{P}^{2} \\
(\mathrm{HO}: \beta 1=1)\end{array}$ & $\begin{array}{c}\mathrm{P}^{3} \\
(\mathrm{HO}: \beta 0=0 \text { and } \beta 1=1)\end{array}$ \\
\hline NRC 2000 & 0.269 & 1.274 & 1.063 & 0.854 & 0.600 & 0.867 & $<0.001$ \\
NRC 2016 & 0.294 & 4.187 & 0.504 & 0.788 & 0.002 & 0.004 & $<0.001$ \\
BR-Corte 2010 & 0.347 & 3.317 & 0.737 & 0.763 & 0.027 & 0.236 & $<0.001$ \\
BR-Corte 2016 & 0.338 & 2.369 & 0.876 & 0.774 & 0.180 & 0.641 & $<0.001$ \\
\hline NRC 2000 & 0.180 & 2.272 & 1.116 & 1.641 & 0.447 & 0.746 & $<0.001$ \\
NRC 2016 & 0.311 & 5.311 & 0.438 & 1.347 & $<0.001$ & $<0.001$ & $<0.001$ \\
BR-Corte 2010 & 0.076 & 4.107 & 0.769 & 1.847 & 0.294 & 0.566 & $<0.001$ \\
BR-Corte 2016 & 0.266 & 1.450 & 0.992 & 1.468 & 0.566 & 0.974 & $<0.001$ \\
\hline
\end{tabular}

$\mathrm{R}^{2} \mathrm{a}=$ adjusted coefficient of determination; $\beta_{0}=$ intercept; $\beta_{1}=$ slope; $\mathrm{SEM}=$ standard error of the mean; $\mathrm{P}$ value $=$ probability of significance at $1 \% ; P^{1}$ value $=$ probability of significance at $1 \%$ of $\beta_{0}=0$ and $\beta_{1}=1$, simultaneously.

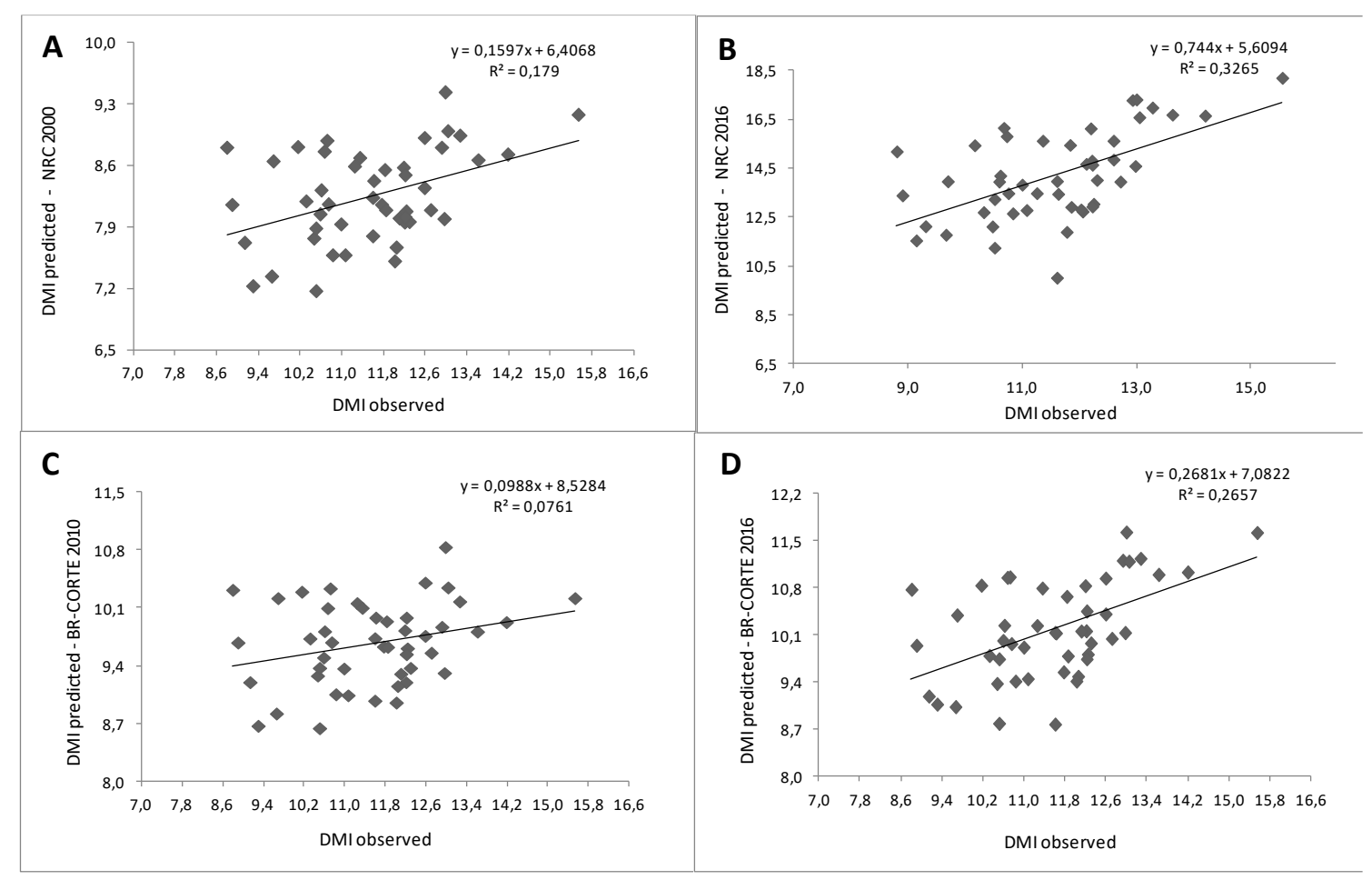

Figure 1. Dry matter intake observed and predicted by nutritional models for the Nellore bulls (kg.day $\left.{ }^{-1}\right)$. A - dry matter intake observed and predicted by NRC (2000); B - dry matter intake observed and predicted by NRC (2016); C - dry matter intake observed and predicted by BR-Corte (2000); D - dry matter intake observed and predicted by BR-Corte (2016). 

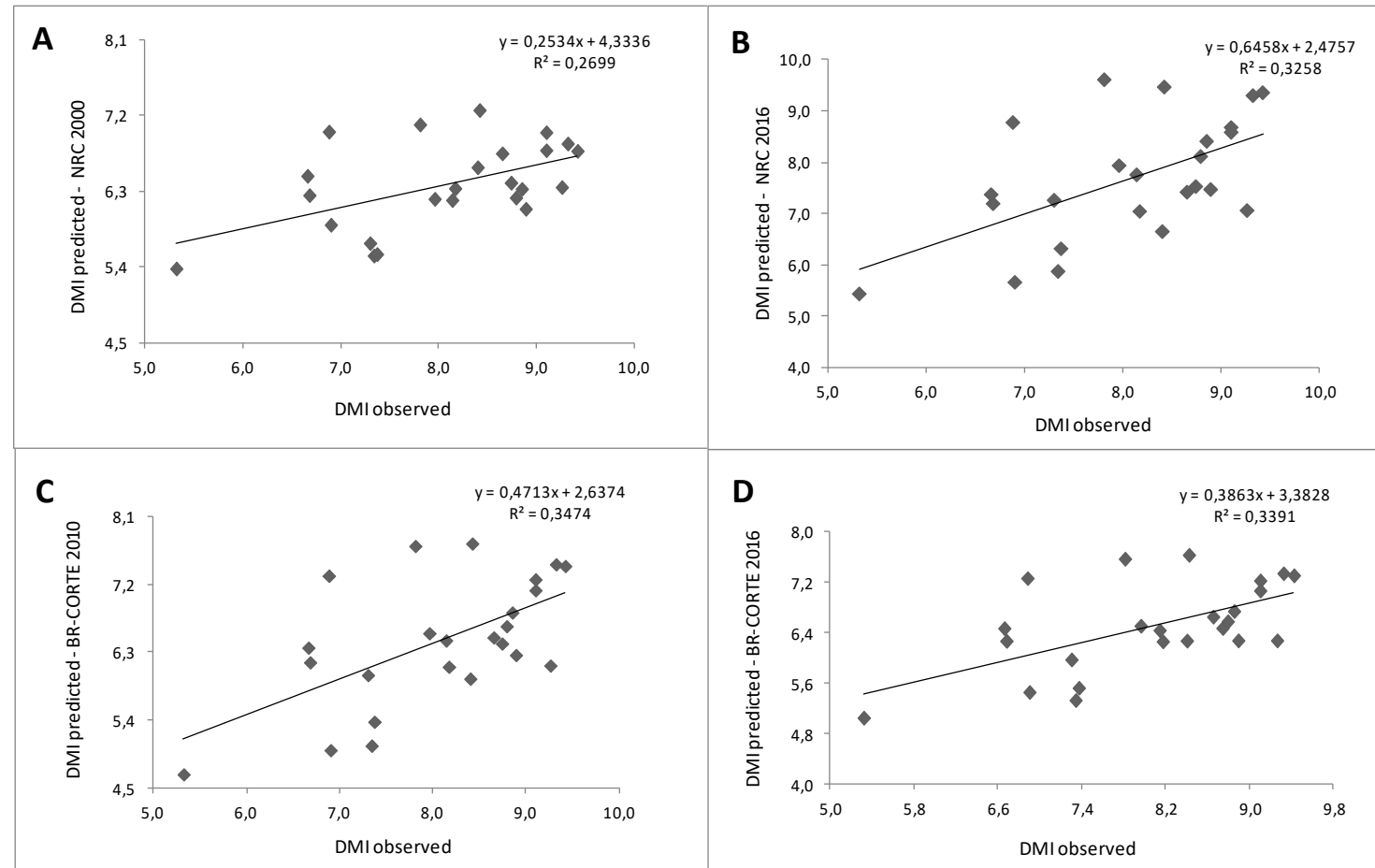

Figure 2. Dry matter intake observed and predicted by nutritional models for Nellore heifers (kg.day ${ }^{-1}$ ). A dry matter intake observed and predicted by NRC (2000); B - dry matter intake observed and predicted by

NRC (2016); C - dry matter intake observed and predicted by BR-Corte (2000); D - dry matter intake observed and predicted by BR-Corte (2016).

The MSEP and its decomposition were low for Nellore heifers, indicating that the predicted values were close to the observed values for both models, and the NRC 2016 was more appropriate for this criterion (Table 5). Moreover, the lowest mean deviation was identified in the NRC 2016 model and most of the errors associated with the model were random, indicating the need for further evaluations to ensure there is no lack of adjustment.

Table 5. Model evaluations by the mean square error of prediction (MSEP) and its decomposition for Nellore heifers.

\begin{tabular}{ccccc}
\hline & NRC 2000 & NRC 2016 & BR-Corte 2010 & BR-Corte 2016 \\
\hline MSEP & 3.59 & 1.20 & 3.38 & 3.16 \\
Variance of MSEP & 6.7 & 1.81 & 6.03 & 5.24 \\
Standard deviation of MSEP & 2.59 & 1.34 & 2.45 & 2.28 \\
CV of MSEP (\%) & 72.04 & 111.69 & 72.49 & 72.35 \\
Square root of MSEP & 1.89 & 1.09 & 1.84 & 1.77 \\
Mean bias & 1.67 & 0.38 & 1.62 & 1.56 \\
CD & 0.35 & 0.71 & 0.32 & 0.37 \\
MEF & -2.35 & -0.12 & -2.16 & -1.95 \\
CCC (rC+-SE) & 0.13 & 0.53 & 0.23 & 0.21 \\
Cb (bias correction) & 0.26 & 0.95 & 0.40 & 0.36 \\
\hline Mean deviation (\%) & 78.19 & 12.01 & 77.95 & 77.35 \\
Systematic deviation (\%) & 0.03 & 27.95 & 1.39 & 0.23 \\
Random errors (\%) & 21.77 & 60.04 & 20.66 & 22.42 \\
\hline
\end{tabular}

MSEP = mean square error of prediction; Mean bias = average trend between the data; $C D=$ coefficient of determination model; $\mathrm{MEF}=$ modeling efficiency; $\mathrm{CCC}=$ concordance correlation coefficient; $\mathrm{Cb}=$ bias correction factor.

The values of mean biases allow inferring that both predicted and observed values are scattered but, among them, the NRC 2016 has better uniformity. Mean bias is the average trend calculated by the average difference between observed values and the ones predicted by the model (Cochran and Cox 1957), in which 
a mathematical model can present a lower trend estimate if the data points are evenly spread around the $Y$ $=\mathrm{X}$ line (Tedeschi 2006).

The concordance correlation coefficient (CCC) evaluates model validity and whether the predicted values are accurate and precise at the same time in intervals or along the original linear trend line. High values and close to 0.9 are ideal. The point that component $p$ (correlation coefficient) measures model accuracy and $\mathrm{Cb}$ (bias correlation factor) indicates the extent to which the regression line deviates from the slope of the unit $\left(45^{\circ}\right)$, varying from 0 to 1 , in which $\mathrm{Cb}=1$ indicates no deviation from the $\mathrm{Y}=\mathrm{X}$ line (Tedeschi 2006). The $\mathrm{CCC}$ and $\mathrm{Cb}$ values (Table 5) allow concluding that, for Nellore heifers, the model suggested by the NRC 2016 was more adequate than the NRC 2000 and BR-Corte.

Anele et al. (2014) evaluated the utility of the DMIR approach for predicting DMI by growing-finishing cattle and found that it represented the highest percentage of variation in observed DMI and had the least root mean square error values in all data sets evaluated. This approach should be considered to predict DMI by growing-finishing beef cattle. Additionally, the control of DMI by ruminants is complex and multifactorial (Forbes 2003) and using only BW and NEm concentration of the diet as independent variables does not consider these additional sources of variation affecting DMI.

The MSEP values and their decomposition for Nellore bulls showed that the BR-Corte 2016 model was more suitable than the NRC and BR-Corte 2010 due to the lower MSEP values than the others (Table 6). As for MSEP decomposition (Table 6), the BR-Corte 2016 model also presented lower systemic deviation (0.001), greater random error (42.91), mean bias (1.36) with values more uniformly spread, and CCC (0.24), which allowed inferring simultaneously a low precision and accuracy of the results, as the regression line deviates from the slope with lower intensity than the other models $(\mathrm{Cb}=0.47)$. The total variation of the observed data also presented better predictions $(C D=0.8)$. In conclusion, for Nellore bulls, the model suggested by the BR-Corte 2016 is more appropriate than the NRC and BR-Corte 2010.

Table 6. Model evaluations by the mean square error of prediction (MSEP) and its decomposition for Nellore bulls.

\begin{tabular}{ccccc}
\hline & NRC 2000 & NRC 2016 & BR-Corte 2010 & BR-Corte 2016 \\
\hline MSEP & 12.04 & 9.35 & 5.29 & 3.27 \\
Variance of MSEP & 64.61 & 79.61 & 29.57 & 10.07 \\
Standard deviation of MSEP & 8.03 & 8.92 & 5.43 & 3.17 \\
CV of MSEP (\%) & 66.71 & 95.38 & 102.67 & 96.92 \\
Square Root of MSEP & 3.47 & 3.06 & 2.3 & 1.8 \\
Mean bias & 3.23 & -2.65 & 1.87 & 1.36 \\
CD & 0.17 & 0.18 & 0.51 & 0.8 \\
MEF & -5.29 & -3.88 & -1.76 & -0.71 \\
CCC (rC+-SE) & 0.05 & 0.23 & 0.07 & 0.24 \\
Cb (bias correction) & 0.12 & 0.41 & 0.24 & 0.47 \\
\hline Mean deviation (\%) & 86.93 & 75.30 & 66.36 & 57.09 \\
Systematic deviation (\%) & 0.03 & 10.91 & 0.25 & 0.001 \\
Random errors (\%) & 13.04 & 13.79 & 33.39 & 42.91 \\
\hline
\end{tabular}

MSEP = mean square error of prediction; Mean bias = average trend between the data; $C D$ = coefficient of determination model; $\mathrm{MEF}=$ modeling efficiency; $\mathrm{CCC}=$ concordance correlation coefficient; $\mathrm{Cb}=$ bias correction factor.

According to Valadares Filho et al. (2006), the NRC equations are inadequate to predict the DMI of beef cattle in the feedlot when fed under tropical conditions, regardless of the racial group, weight gain rate, and sex. However, the factors that control feed intake are complex and the interactions between these numerous factors are mainly responsible for the lack of precision of the DMI prediction equations (Mcmeniman et al. 2009). Thus, for this study, the models proposed by the BR-Corte were more appropriate to estimate DMI for Nellore bulls because they were developed from a database of Bos indicus cattle and fed tropical forage. 
Ribeiro et al. (2012) evaluated the prediction of DMI by the CNCPS 5.0, NRC, and BR-Corte for 44 Nellore PO (pure of origin), Nellore LA (open book), Tabapuã PO, and Guzerá PO breed, with an average initial body weight of 394, 348, 346, and $340 \mathrm{~kg}$, respectively, and feeding with a rough and concentrated 30:70 ratio. The authors concluded that the systems underestimated the $\mathrm{DMI}$ and were not adequate to predict the DMI of Zebu bulls in the feedlot. Although the average intake observed ( $\left.8.85 \mathrm{~kg} \mathrm{day}^{-1}\right)$ is close to that predicted by the systems (CNCPS: 7.85, NRC: $8.29, \mathrm{Br}$-Corte 8.58 ), they believe that the difference may concern the high dispersion of the observed data relative to the predicted data.

Kleijnen et al. (1998) stated that rigorous assumptions require that a mathematical model is valid as long as the values observed and predicted by the model have identical means, identical variations, and are positively correlated. Unfortunately, these conditions are rarely contemplated by mathematical models used under practical conditions. According to Valadares Filho et al. (2016), it would be correct to develop DMI prediction equations specific to each production system, which should consider most DMI variations when compared to a generalized equation.

\section{Conclusions}

The models for predicting dry matter intake for cattle proposed by the BR-Corte 2010 and 2016 systems were more appropriate to estimate the dry matter intake of Nellore bulls. For Nellore heifers, the NRC 2016 model was more appropriate.

Authors' Contributions: FERREIRA, A.M.S.: acquisition of data, analysis and interpretation of data, drafting the article; ILVA, S.P.: conception and design, acquisition of data, analysis and interpretation of data, drafting the article; FARIA, C.U.: conception and design, acquisition of data, analysis and interpretation of data, drafting the article; MENDES, E.D.M.: acquisition of data, analysis and interpretation of data; FELIPE, E.F.: acquisition of data, analysis and interpretation of data, drafting the article. All authors have read and approved the final version of the manuscript.

Conflicts of Interest: The authors declare no conflicts of interest.

Ethics Approval: Not applicable.

Acknowledgments: The authors would like to thank the funding for the realization of this study provided by the Brazilian agency CNPq (Conselho Nacional de Desenvolvimento Científico e Tecnológico - Brasil).

\section{References}

AFERRI, G. Exigências de energia e proteína e composição do ganho em peso compensátorio de novilhos Nelore por meio do indicador óxido de deutério. Tese (Doutorado). Pirassununga: Faculdade de Zootecnia e Engenharia de Alimentos, Universidade de São Paulo, 2007. Available from: www.teses.usp.br/teses/disponiveis/74/74131/tde-08022008.../DO1051340.pdf

ANELE, U. Y., DOMBY E.M. and GALYEAN, M.L. Predicting dry matter intake by growing and finishing beef cattle: Evaluation of current methods and equation development. Journal of Animal Science. 2014, 92, 2660-2667. https://doi.org/10.2527/jas.2014-7557

BARBOSA, F.A., et al. Ganho compensatório no desempenho e eficiência econômica de novilhos Nelore submetidos a diferentes regimes alimentares. Arquivo Brasileiro de Medicina Veterinária e Zootecnia. 2016, 68(1), 182-190. https://doi.org/10.1590/1678-4162-8212

BERCHIELLI, T.T., PIRES, A.V. and OLIVEIRA, S.G. Nutrição de Ruminantes. 2nd ed. Jaboticabal : FUNEP Fundação de Apoio a Pesquisa, Ensino e Extensão, 2011.

COCHRAN, W.G. and COX, G.M. Experimental Design. 2nd ed. New York: Wiley, 1957.

DETMANN, E., et al. Métodos para Análise de Alimentos. Visconde do Rio Branco: Suprema, 2012.

FERNANDES, H.J., et al. Ganho de Peso, Conversão alimentar, ingestão diária de nutrientes e digestibilidade de garrotes não castrados de três grupos genéticos em recria e terminação. Revista Brasileira de Zootecnia. 2004, 33(6), 2403-2411. https://doi.org/10.1590/S1516-

$\underline{35982004000900029}$

FORBES, J.M. The multifactorial nature of food intake control. Journal Animal Science. 2003, 81(2), 139-144.

https://doi.org/10.2527/2003.8114 suppl 2E139x

FOX, D.G., TYLUTKI, T.P. and TEDESCHI, L.O. Sistema de carboidratos e proteínas líquidos para avaliação da nutrição de rebanhos e excreção de nutrientes (CNCPS Versão 5.0). Juiz de Fora: Embrapa Gado de Leite, 2003.

KLEIJNEN, J.P.C., BETTONVIL, B. and VAN GROENENDALL, W. Validation of trace-driven simulation models: a novel regression test.

Management Science. 1998, 44, 812-819. https://doi.org/10.1287/mnsc.44.6.812 
KOBAYASHI, K. and SALAM, M.U. Comparing simulated and measured values using mean squared deviation and its components. Agronomy Journal. 2000, 92(2), 345-352. https://doi.org/10.1007/s100870050043

MARCONDES, M.I., et al. Consumo e desempenho de animais alimentados individualmente ou em grupo e características de carcaça de animais Nelore de três classes sexuais. Revista Brasileira de Zootecnia. 2008, 37(12), 2243-2250. https://doi.org/10.1590/S1516$\underline{35982008001200023}$

MCMENIMAN, J.P., DEFOOR, P.J. and GALYEAN, M.L. Evaluation of the national research council (1996) dry matter intake prediction equations and relationships between intake and performance by feedlot cattle. Journal of Animal Science. 2009, 87(3), 1138-1146.

https://doi.org/10.2527/jas.2008-1326

NATIONAL RESEARCH COUNCIL - NRC. Nutrient requirements of beef cattle. 7th ed. rev. Washington: The National Academies Press, 2000.

National Research Council - NRC. Nutrient Requirements of Dairy Cattle. 7th ed. Washington, DC: The National Academies Press, 2001.

NATIONAL RESEARCH COUNCIL - NRC. Nutrient requirements of beef cattle. 8th ed. Washington, DC: The National Academies Press, 2016.

PAULINO, P.V.R., et al Desempenho produtivo de bovinos nelore de diferentes classes sexuais alimentados com dietas contendo dois níveis de oferta de concentrado. Revista Brasileira de Zootecnia. 2008, 37(6), 1079-1087. https://doi.org/10.1590/S1516-35982008000600019

RIBEIRO, J.S., et al. Consumo alimentar e sua predição pelos sistemas NRC, CNCPS e BR-CORTE, para tourinhos zebuínos confinados. Revista Ciência Agronômica. 2012, 43(4), 802-810. https://doi.org/10.1590/S1806-66902012000400023

RUBIANO, G.A.G., et al. Desempenho, características de carcaça e qualidade da carne de bovinos superprecoces das raças Canchim, Nelore e seus mestiços. Revista Brasileira de Zootecnia. 2009, 38(12), 2490-2498. https://doi.org/10.1590/S1516-35982009001200027

TEDESCHI, L.O. Model evaluation System. version 3.1.17. 2017. Available from: http://nutritionmodels.com/mes.html

TEDESCHI, L.O. Assessment of the adequacy of mathematical models. Agricultural Systems. 2006, 89, 225-247.

https://doi.org/10.1016/j.agsy.2005.11.004

VALADARES FILHO, S.C., PAULINO, P.V.R. and MAGALHÃES, K.A. Exigências nutricionais de zebuínos e tabelas de composição de alimentos BRCorte. Viçosa - MG: UFV, 2006.

VALADARES FILHO, S.C., et al. Exigências nutricionais de zebuínos puros e cruzados BR-Corte. 2nd ed. Viçosa - MG: UFV, 2010.

VALADARES FILHO, S.C., et al. BR-CORTE 3.0. Cálculo de exigências nutricionais, formulação de dietas e predição de desempenho de zebuínos puros e cruzados. 3. ed. Viçosa - MG: UFV, 2016.

Received: 25 April 2020 | Accepted: 20 January 2021 | Published: 29 December 2021

This is an Open Access article distributed under the terms of the Creative Commons Attribution License, which permits unrestricted use, distribution, and reproduction in any medium, provided the original work is properly cited. 